\title{
120 radców skarbowych jako „elita” Krajowej Administracji Skarbowej
}

\section{0 officers employed as revenue collectors as the "elite" of the National Revenue Administration}

Streszczenie. Publikacja poświęcona jest instytucji radcy skarbowego, która funkcjonuje w polskim systemie podatkowym od 1 marca 2017 r. wraz z utworzeniem Krajowej Administracji Skarbowej. Wyniki przeprowadzonych badań empirycznych potwierdziły, że stanowisko radcy skarbowego to jedynie „nieefektywna posada urzędnicza” w strukturach administracji podatkowej (skarbowej). Ponadto badania ujawniły m.in., że 58,33\% radców skarbowych nie posiada kierunkowego wykształcenia wyższego o profilu prawno-podatkowym, właściwego do wymiaru, poboru i egzekucji danin publicznoprawnych.

Słowa kluczowe: radca skarbowy; Krajowa Administracja Skarbowa; pracownik; funkcjonariusz; wynagrodzenie; uposażenie; polityka.

\begin{abstract}
This article is devoted to an institution of officers employed as revenue collectors. This institution has been functioning in the Polish tax system since 1 March 2017, so since an establishment of the National Revenue Administration.
\end{abstract}


Results of an empirical research have confirmed that the position of the officer is merely an "ineffective clerical post" in the structures of the tax (treasury) administration. In addition, the analysis revealed, among other things, that $58.33 \%$ of officers employed as a revenue collectors do not have a university degree with a legal and tax profile relevant to the assessment, collection and enforcement of public and legal levies.

Keywords: officers employed as revenue collectors; the National Revenue Administration; employee; officer; salary; emolument; policy.

\section{Uwagi wprowadzające}

Celem publikacji jest ustalenie ratio legis powołania stanowiska radcy skarbowego, wprowadzonego do polskiego systemu prawnego z dniem 1 marca 2017 r. wraz z nową strukturą organizacyjną danin publicznych Krajową Administracją Skarbową. Ponadto na podstawie materiału empirycznego, uzyskanego głównie od dyrektorów izb administracji skarbowej, podjęto próbę przedstawienia „reguł”, według których powoływano (wyłaniano) radców skarbowych, co do zasady poprzez pryzmat ich kierunkowego wykształcenia. W opracowaniu wskazano także liczbę wydanych przez radców skarbowych rozstrzygnięć podatkowych oraz ich wynagrodzenia (uposażenia) względem pozostałych pracowników (funkcjonariuszy) Krajowej Administracji Skarbowej.

Użyte w tytule pojęcie „elita” w konfrontacji z treścią publikacji ma charakter przewrotny. Oczywiście jest to bez wątpienia zamierzone działanie autora, który krytycznie ocenia zarówno „poczynania ustawodawcze” w zakresie pomnażania nowych stanowisk urzędniczych w administracji podatkowej (skarbowej), jak i „uznaniowość” dyrektorów izb administracji skarbowej w wyłanianiu kandydatów na radców skarbowych poprzez pryzmat ich „warsztatu podatkowego”. Autor ma świadomość, że liczba radców skarbowych będzie stale się zmieniać, jednakże w celu przeprowadzenia metodologicznie poprawnych badań przyjął liczbę 120 radców skarbowych (również w tytule artykułu), którzy na dzień 31 grudnia 2020 roku są zatrudnieni (powołani) w jednostkach organizacyjnych Krajowej Administracji Skarbowej. 


\section{Ratio legis powołania radcy skarbowego w świetle utworzenia Krajowej Administracji Skarbowej}

Z dniem 1 marca 2017 r. ustawą z 16 listopada 2016 r. o Krajowej Administracji Skarbowej ${ }^{1}$ oraz ustawą z 16 listopada 2016 r. przepisy wprowadzające ustawę o Krajowej Administracji Skarbowej² ustawodawca dokonał tzw. konsolidacji administracji podatkowej, służby celnej i kontroli skarbowej $^{3}$, tworząc Krajową Administrację Skarbową ${ }^{4}$. Między innymi w ramach powyższej reformy administracji finansów publicznych ${ }^{5}$ artykułem 38 pkt 3 lit. c) u.p.w.KAS. dodano do art. 13 ustawy z dnia 29 sierpnia 1997 r. Ordynacja podatkowa ${ }^{6} \S 2$ c, zgodnie z którym w zakresie rozstrzygania spraw podatkowych uprawnienia naczelnika urzędu skarbowego, naczelnika urzędu celno-skarbowego oraz dyrektora izby administracji skarbowej, jako organu podatkowego, przysługują także radcy skarbowemu, wykonującemu czynności orzecznicze w tym organie ${ }^{7}$. Nie ulega jednak wątpliwości, że radca skarbowy nie jest organem podatkowym,

Tekst jedn. Dz.U. z 2021 r., poz. 422 ze zm.; dalej: u.KAS.

Dz.U. z 2016 r., poz. 1948 ze zm.; dalej: u.p.w.KAS.

I. Nowak, National Revenue Administration - current organisational and financial problems, „Prawo Budżetowe Państwa i Samorządu” 2020, nr 2, s. 37 i n., DOI: http://dx.doi.org/10.12775/PBPS.2020.010.

4 Szerzej A. Melezini, K. Teszner (red.), Krajowa Administracja Skarbowa. Komentarz, Warszawa 2018; I. Nowak, Krajowa Administracja Skarbowa w świetle „standardów” stanowionego prawa oraz polityki kadrowo-płacowej - uwagi krytyczne, „Prawo Budżetowe Państwa i Samorządu” 2021, nr 2, s. 41-66, DOI: http://dx.doi.org/10.12775/PBPS.2021.008.

5 K. Teszner, Customs and Fiscal Control in Poland as a Radical Measure to Eliminate Tax Evasion, „Intertax” 2020, Vol. 48, Issue 10, s. 922; tenże The National Fiscal Administration - challenges and expectations [w:] E. Lotko, U.K. Zawadzka-Pąk, M. Radvan (red.), Optimization of Organization and Legal Solutions Concerning Public Revenues and Expenditures in Public Interest, Białystok 2018, p. 563-576.

6 Ustawa z dnia 29 sierpnia 1997 r. Ordynacja podatkowa (tekst jedn. Dz.U. z 2021 r., poz. 1540 ze zm.), dalej: o.p.

7 Szerzej K. Teszner, Uprawnienia radcy skarbowego $w$ zakresie załatwiania spraw podatkowych, „Procedury Administracyjne i Podatkowe” 2018, nr 2, s. 17-24; tenże Komentarz do art. 13 o.p. [w:] L. Etel (red.), Ordynacja podatkowa. Komentarz, LEX/el. 2021; I. Nowak, An officer employed as a revenue collector in the structure of the National Revenue Administration - critical remarks, „Prawo Budżetowe Państwa i Samorządu” 2020, nr 3, s. 89-113, DOI: http://dx.doi.org/10.12775/PBPS.2020.019. 
a jedynie pracownikiem (funkcjonariuszem), do którego obowiązków należy rozstrzyganie spraw podatkowych na mocy art. 13 § 2c o.p. ${ }^{8}$. Innymi słowy, w świetle powyższego przypisu radca skarbowy został umocowany expressis verbis do wykonywania „czynności orzeczniczych” wyłącznie w enumeratywnie wymienionych państwowych organach podatkowych. Tym samym w ramach postępowania podatkowego radca skarbowy jest uprawniony do wydawania indywidualnych aktów administracyjnych w procesowej formie decyzji i postanowień ${ }^{9}$.

Niestety, zarówno w uzasadnieniu projektu ustawy z dnia 16 listopada 2016 r. o Krajowej Administracji Skarbowej, jak również w uzasadnieniu projektu ustawy z dnia 16 listopada 2016 r. przepisy wprowadzające ustawę o Krajowej Administracji Skarbowej projektodawca nie sformułował żadnych reguł czy motywów utworzenia stanowiska radcy skarbowego. Czyżby dlatego, że powyższe projekty aktów prawnych nie przeszły stosownych konsultacji, gdyż były projektami poselskimi, zwolnionymi z tego trybu? ${ }^{10}$ Warto podkreślić, że prace nad projektami ustaw reformujących administrację danin publicznoprawnych prowadzone były de facto $\mathrm{w}$ Ministerstwie Finansów ${ }^{11}$, chociaż „doświadczenia ostatniego dziesięciolecia wskazują na to, że reforma prawa podatkowego niezależnie od zasięgu zmian w systemie opodatkowania z rozmaitych i na ogół znanych powodów wykracza poza możliwości Ministerstwa Finansów"12. Innymi słowy, praktyka resortowego ${ }^{13}$ (departamentowego ${ }^{14}$ ) tworzenia

8 B. Brzeziński, M. Kalinowski, A. Olesińska (red.), Ordynacja podatkowa. Komentarz praktyczny, Gdańsk 2017, s. 74; I. Nowak, An officer..., s. 89-113.

9 Tamże, s. 95.

10 I. Nowak, Funkcjonariusze celni w strukturze Krajowej Administracji Skarbowej uwagi wybrane, „Kwartalnik Prawa Podatkowego” 2019, nr 2, s. 41.

11 Tamże; I. Nowak, Krajowa Administracja Skarbowa w świetle..., s. 45; wypowiedzi podsekretarza stanu w Ministerstwie Finansów podczas posiedzenia Komisji Finansów Publicznych z dnia 18 listopada 2016 r., http://orka.sejm.gov.pl/Zapisy8.nsf/wgskrnr/FPB-116 (dostęp: 2.05.2021 r.); informacja Najwyższej Izby Kontroli z dnia 17 grudnia 2019 r. pt. Stan organizacji Krajowej Administracji Skarbowej, nr ewid. 159/2019/P/18/009/KBF, s. 32; https://www.nik.gov.pl/plik/id,21676,v,artykul_20616.pdf (dostęp: 05.05.2021 r.), dalej: Informacja NIK.

12 B. Brzeziński, W. Nykiel, Stan prawa podatkowego w Polsce. Raport 2010, „Kwartalnik Prawa Podatkowego" 2011, nr 1, s. 83.

13 Tamże, s. 62 i n. 
prawa, a następnie przedstawiania go jako projekty poselskie ${ }^{15}$, to nic innego jak upolitycznienie legislacji przez większość parlamentarną i nolens volens „prawny faryzeizm”16, prowadzący do katastrofy prawnej ${ }^{17}$ i skutkujący co do zasady tym, że „w chwili obecnej stopień dekompozycji wszystkich właściwie tekstów aktów normatywnych oznacza konieczność sporządzenia ich on nowa”"18. Przypomina to „analogię do sytuacji rozbitków morskich, którzy wyrzucili za burtę kompas i w celu określenia kierunków geograficznych podejmują rozpaczliwe próby ich wskazania poprzez głosowanie. Jest to wprawdzie bardzo demokratyczna metoda, ale czy rzeczywiście północ będzie tam, gdzie zadecydowała o tym większość"19?

Biorąc pod uwagę fakt, że projekty ustaw o Krajowej Administracji Skarbowej de facto powstały w Ministerstwie Finansów, należy uznać, iż wyjaśnienia dyrektorów Departamentu Systemu Podatkowego oraz Departamentu Reformy Administracji Skarbowej, przedstawione na Komisji Finansów Publicznych w dniu 15 listopada 2016 r. (nota bene dzień przed uchwaleniem ustaw o Krajowej Administracji Skarbowej) w zakresie

14 B. Brzeziński, W. Nykiel, Reforma systemu podatkowego - aspekty prawne, „Przegląd Podatkowy” 2003, nr 6, s. 4.

15 Prawo do dobrego prawodawstwa podatkowego - zob. poselski projekt ustawy - Karta Praw Podatnika z 2019 r. (druk nr 3458, Sejm RP VIII kadencji), https://www.sejm.gov.pl/Sejm8.nsf/druk.xsp?nr=3458 (dostęp: 05.05.2021 r.); szerzej W. Nykiel, Prawa podatnika a stanowienie prawa podatkowego - wybrane zagadnienia, „Kwartalnik Prawa Podatkowego” 2019, nr 4, s. 12; B. Brzeziński, Deklaracja Praw Podatnika. Propozycja systematyzacji tez, „Prawo i Podatki” 2008, nr 4, wyd. specjalne, s. 3-6; tenże Kwartał po ogłoszeniu Deklaracji Praw Podatnika - i co dalej? Wywiad z prof. dr. hab. Bogumiłem Brzezińskim, „Prawo i Podatki” 2011, nr 9, s. 1-4; M. Wilk, Potrzeba wprowadzenia Karty Praw Podatnika w Polsce, „Kwartalnik Prawa Podatkowego" 2018, nr 1, s. 97-104.

16 A. Kidyba, Osiem grzechów głównych, „Dziennik Gazeta Prawna” z dnia 16 lutego 2021, nr 31 (5439), s. D3.

17 I. Nowak, Funkcjonariusze..., s. 42; zob. także A. Gomułowicz, Konstytucyjny aspekt stanowienia obowiq̨zków podatkowych [w:] M. Bogucka (red.), Finanse publiczne a Konstytucja, Warszawa 2020, s. 26-27.

18 Szerzej B. Brzeziński, K. Lasiński-Sulecki, W. Morawski, Poprawa efektywności polskiego systemu podatkowego w świetle zasad polityki podatkowej i tworzenia prawa, „Przegląd Orzecznictwa Podatkowego” 2020, nr 6, s. 429.

19 W. Łączkowski, Prawo naturalne a prawo stanowione. Uwagi prawnika, „Ethos” 1999, nr 1-2, s. 180. 
instytucji radcy skarbowego należy uznać za w pełni wiarygodne i miarodajne $^{20}$. L. Grzybowski, dyrektor Departamentu Systemu Podatkowego w Ministerstwie Finansów, twierdził, że ,jeśli chodzi o instytucję radcy skarbowego, to jest to stanowisko pracy. Intencją tego przepisu jest skupienie, dla potrzeb funkcji orzeczniczej, pracowników o szczególnych kwalifikacjach, najwyższych kwalifikacjach w administracji skarbowej, którzy w imieniu organu, ale podpisując własnym imieniem, będą wydawali decyzje, ponosząc w związku z taką konstrukcją również odpowiedzialność osobistą za kształt i treść decyzji”21. Ponadto zauważył, że „liczba radców skarbowych uzależniona jest od zakresu orzecznictwa w urzędzie skarbowym. Wielkość urzędów jest bardzo zróżnicowana, liczba wydanych decyzji również jest zróżnicowana, więc to będzie w każdym urzędzie dopasowane do zadań. Ma to być związane z zadaniami. Oczywiście w minimalnym zakresie tak, aby zminimalizować wydatek Skarbu Państwa na ten cel, ale też tak, aby docenić pracowników, którzy mają szczególną wiedzę i charakteryzują się zaangażowaniem”22.

W podobnym duchu wypowiadała się także dyrektor Departamentu Reformy Administracji Skarbowej w Ministerstwie Finansów H. Łopianowska, podnosząc, że „radca skarbowy, jak to zostało powiedziane, to stanowisko służbowe, jedno z wielu w siatce możliwych stanowisk, na którym to stanowisku dyrektor, naczelnik i kierownik danej jednostki organ będzie mógł upoważnić konkretnego radcę do wydawania w jego imieniu decyzji tak, jak dzisiaj to czyni, w zgodzie z praktyką, która funkcjonuje w wielu organach podatkowych, w wielu organach administracji publicznej, upoważniając konkretnego pracownika do wydawania rozstrzygnięć w określonym zakresie”23.

20 Pełny zapis przebiegu posiedzenia Komisji Finansów Publicznych z dnia 15 listopada 2016 r., nr 135 (VIII kadencji Sejmu RP),

https://orka.sejm.gov.pl/zapisy8.nsf/0/1D776C85660F89FAC125807A004DAC7F/\%2 4File/0124208.pdf (dostęp: 05.05.2021 r.), dalej: Komisja Finansów Publicznych (nr 135), (dostęp: 11.05.2021 r.).

21 Tamże.

22 Tamże.

23 Tamże. 
Podsumowując przedstawione powyższej stanowiska dyrektorów departamentów w Ministerstwie Finansów, należy podkreślić, że już po zestawieniu art. 13 § 2c o.p. z art. 143 o.p. (normującym tzw. upoważnienie administracyjne ${ }^{24}$ ) widać irracjonalność ustanowienia instytucji radcy skarbowego, ponieważ jest to superfluum ustawowe, skutkujące zbędnym i podwójnym wyrażeniem tej samej normy podatkowoprawnej w jednym akcie prawnym ${ }^{25}$. Innymi słowy, normodawca nie musiał wprowadzać przepisu art. 13 § 2c o.p., ponieważ kierownik każdej jednostki organizacyjnej doskonale wie, który z jego pracowników (funkcjonariuszy) jest „profesjonalistą” w zakresie tematyki danin publicznoprawnych i w ramach upoważnienia administracyjnego z art. 143 o.p. w każdej chwili może go umocować do załatwiania spraw podatkowych w jego imieniu ${ }^{26}$. Należy ponadto zwrócić uwagę, że wyniki przeprowadzonych badań empirycznych potwierdzają, że radcowie skarbowi posiadają na mocy art. 143 o.p. upoważnienie do wykonywania czynności orzeczniczych, udzielone im przez monokratyczny organ podatkowy np. w postaci zakresu obowiązków, odpowiedzialności i uprawnień pracownika, w którym wskazuje się szczegółowy zakres upoważnień do podpisywania rozstrzygnięć w imieniu organu ${ }^{27}$. Warto także podkreślić, że już 2 listopada 2016 r. pracownicy Biura Legislacyjnego Kancelarii Senatu zgłaszali różnorakie wątpliwości odnośnie instytucji radcy skarbowego, m.in. trafnie zauważali, iż zgodnie z art. 143 o.p. organ podatkowy może upoważnić pracownika kierowanej jednostki organizacyjnej do załatwiania spraw

24 Szerzej I. Nowak, Upoważnienie pracownika do załatwiania spraw w imieniu samorzq̨dowego organu podatkowego, „Przegląd Podatków Lokalnych i Finansów Samorządowych” 2017, nr 10, s. 19-27.

25 I. Nowak, An officer..., s. 96.

26 Tamże.

27 Tak na przykład w Izbie Administracji Skarbowej w Warszawie - pismo Dyrektora IAS w Warszawie z dnia 20 stycznia 2021 r., nr 1401-IWK-2.0150.8.2021, pozyskane w trybie ustawy o dostępie do informacji publicznej (tekst jedn. Dz.U. z 2020 r., poz. 2176 ze zm.). W przypadku pozostałych pism organów administracji podatkowej, przy których brak będzie informacji o bazie, w której są one dostępne, należy rozumieć, że zostały uzyskane na podstawie powyższego aktu prawnego. 
w jego imieniu, w tym wydawania decyzji, a instytucja radcy skarbowego wydaje się „wpisywać” w to właśnie rozwiązanie ${ }^{28}$.

Mając na uwadze wszystkie powyższe ustalenia, należy zauważyć, że w literaturze prawa podatkowego wskazano, iż motywy powołania przez ustawodawcę stanowiska radcy skarbowego można także wytłumaczyć „likwidacją instytucji inspektora kontroli skarbowej i koniecznością wypełnienia”29 tego braku. Jednakże ze zgromadzonego przez autora materiału empirycznego wynika, że na 120 radców skarbowych tylko 30 było wcześniej zatrudnionych na tym stanowisku (zob. tabela 1).

\section{Reguły „powoływania” radców skarbowych w jednostkach organizacyjnych Krajowej Administracji Skarbowej}

Dyrektor Departamentu Systemu Podatkowego w Ministerstwie Finansów L. Grzybowski na posiedzeniu Komisji Finansów Publicznych w dniu 15 listopada 2016 r. wskazał, że „liczba radców skarbowych uzależniona jest od zakresu orzecznictwa w urzędzie skarbowym (...) Dzisiaj nie możemy podać konkretnej liczby, bo ta liczba zostanie wyłoniona w trakcie funkcjonowania. Warunkiem określającym liczbę będzie potrzeba, czyli zadania w tym zakresie»30. Analogicznie argumentowała także dyrektor Departamentu Reformy Administracji Skarbowej Ministerstwa Finansów H. Łopianowska, podkreślając, iż „nigdy nigdzie nie padła liczba radców skarbowych, która ma być w poszczególnych jednostkach albo w całej Krajowej Administracji Skarbowej”31.

\footnotetext{
28 Opinia do ustawy - Przepisy wprowadzające ustawę o Krajowej Administracji Skarbowej (druk nr 313), Warszawa, dnia 2 listopada 2016 r., https:/www.senat.gov.pl/download/gfx/senat/pl/senatekspertyzy/3638/plik/313.pdf (dostęp: 30.04.2021 r.).

29 M. Łoboda, D. Strzelec, Kontrola przestrzegania przepisów prawa podatkowego, LEX/el. 2017.

30 Komisja Finansów Publicznych (nr 135).

31 Tamże.
} 
W jednostkach organizacyjnych Krajowej Administracji Skarbowej w kwietniu 2018 r. zatrudnionych było 74 radców skarbowych ${ }^{32}$. Na 31 marca 2019 r. liczba ta wzrosła do 8933. Z danych na luty-marzec $2020 \mathrm{r}$. wynika, że było 105 radców skarbowych ${ }^{34}$, natomiast na 31 grudnia 2020 r. jest ich już $120^{35}$ (90 kobiet i 30 mężczyzn) ${ }^{36}$. Warto przy tym zauważyć, że tylko jeden funkcjonariusz Służby Celno-Skarbowej jest radcą skarbowym ${ }^{37}$, a pozostałych 119 to członkowie korpusu służby cywilnej $^{38}$. Trzeba też podkreślić, że dyrektorzy Izb Administracji Skarbowej w Katowicach ${ }^{39}$, Olsztynie ${ }^{40}$ i Opolu ${ }^{41}$ nie zdecydowali się na zatrudnienie (powołanie) w swoich jednostkach organizacyjnych radców skarbowych. Analogicznie było także do 2020 r. w Izbie Administracji Skarbowej w Lublinie ${ }^{42}$.

32 https://orka.sejm.gov.pl/Druki8ka.nsf/0/08D4589E8B6757BFC1258328002ECE6D/ \%24File/2905.pdf (dostęp: 10.01.2021 r.).

33 Pismo Ministra Finansów z dnia 23 sierpnia 2019 r., nr BMI1.0124.926.2019; projekt rozporządzenia Ministra Finansów w sprawie dodatku orzeczniczego na stanowisku radcy skarbowego, https://celnicy.pl/threads/projekt-rozporzadzenia-w-sprawiedodatku-orzeczniczego.16320/ (dostęp: 10.05.2021 r.).

34 Dane za okres luty-marzec 2020 r. pozyskane od Dyrektorów Izby Administracji Skarbowej (dalej IAS) w trybie dostępu do informacji publicznej.

35 Dane za grudzień 2020 oraz styczeń 2021 r. pozyskane od Dyrektorów IAS w trybie dostępu do informacji publicznej.

36 Powyższe proporcje są prawie identyczne jak w całej Krajowej Administracji Skarbowej. Ze sprawozdania Szefa Służby Cywilnej o stanie służby cywilnej i o realizacji zadań tej służby w 2020 r. wynika, że udział zatrudnienia kobiet i mężczyzn według kategorii urzędów (stan na 31.12.2020 r. w osobach) w Krajowej Administracji Skarbowej wynosi 76,1\% do 23,9\% - https://www.gov.pl/web/sluzbacywilna/sprawozdaniessc (dostęp: 8.05.2021 r.).

37 Pismo Dyrektora IAS w Rzeszowie z dnia 24 lutego 2020 r., $\mathrm{nr}$ 1801IWK.0150.21.2020.4.

38 I. Nowak, Radca skarbowy w świetle badań empirycznych [w:] A. Mariański, D. Strzelec, M. Wilk (red.), Wyzwania współczesnego prawa podatkowego. Księga jubileuszowa dedykowana Profesorowi Włodzimierzowi Nykielowi w 70. rocznicę urodzin, Łódź 2021, w druku.

39 Pismo Dyrektora IAS w Katowicach z dnia 29 grudnia 2020 r., nr 2401-IWK.0150. 241.2020.2.

40 Pismo Dyrektora IAS w Lublinie z dnia 30 grudnia 2020 r., nr 2801-IWK.0150. 140.2020.

41 Pismo Dyrektora IAS w Opolu z dnia 28 grudnia 2020 r., nr 1601-IWK.0150. 78.2020.2.

42 W 2020 r. Dyrektor IAS w Lublinie powołał 5 radców skarbowych - pismo Dyrektora IAS w Lublinie z dnia 18 stycznia 2021 r., nr 0601-IWK.0150.104.2020.8. 
Istnieją niczym nieuzasadnione rozbieżności odnośnie wymogów, jakie ustawodawca stawia przed kandydatami na radców skarbowych odnośnie do ich wykształcenia, różnicując je względem członków korpusu służby cywilnej i funkcjonariuszy Służby Celno-Skarbowej. Według rozporządzenia Prezesa Rady Ministrów z dnia 29 stycznia 2016 r. w sprawie określenia stanowisk urzędniczych, wymaganych kwalifikacji zawodowych, stopni służbowych urzędników służby cywilnej, mnożników do ustalania wynagrodzenia oraz szczegółowych zasad ustalania i wypłacania innych świadczeń przysługujących członkom korpusu służby cywilnej ${ }^{43}$ radca skarbowy (stanowisko samodzielne w służbie cywilne) musi posiadać wykształcenie wyższe. Natomiast zgodnie z rozporządzeniem Ministra Rozwoju i Finansów z dnia 27 lutego 2017 r. w sprawie stanowisk służbowych funkcjonariuszy Służby Celno-Skarbowej, trybu awansowania oraz dokonywania zmian na stanowiskach służbowych ${ }^{44}$ radca skarbowy (stanowisko eksperckie) musi posiadać ukończone jednolite studia magisterskie lub studia drugiego stopnia. Wydaje się, że wprowadzone różnice związane z wykształceniem radców skarbowych w powyższych grupach zawodowych wynikać mogą z chaosu legislacyjnego lub z innych trudnych do ustalenia powodów.

Wyniki przeprowadzonych badań empirycznych potwierdziły, że na ponad 10 413,375 etatów funkcjonariuszy Służby Celno-Skarbowej ${ }^{45}$ tylko jeden jest radcą skarbowym ${ }^{46}$. Pozostałych 119 radców skarbowych to członkowie korpusu służby cywilnej (47 707,267 etatów) ${ }^{47}$. Trudno jednak bezwzględnie ustalić, co jest tego przyczyną. A może - brak zaufania do służb mundurowych?

Tekst jedn. Dz.U. z 2021 r., poz. 689.

Tekst jedn. Dz.U. z 2018 r., poz. 1941.

Według pisma Ministra Finansów z dnia 24 czerwca 2020 r., nr DOS11.054. 47.2020.KZM, https://orka2.sejm.gov.pl/INT9.nsf/klucz/ATTBQXEQJ/\%24FILE/ i07349-o1.pdf (dostęp: 2.05.2021 r.).

46 Pismo Dyrektora IAS w Rzeszowie z dnia 24 lutego 2020 r., nr 1801-IWK.0150. 21.2020.4.

47 Według pisma Ministra Finansów z dnia 24 czerwca 2020 r., nr DOS11.054. 47.2020.KZM, https://orka2.sejm.gov.pl/INT9.nsf/klucz/ATTBQXEQJ/\%24FILE/ i07349-o1.pdf (dostęp: 9.05.2021 r.). 
Biorąc pod uwagę fakt, że prawidłowe „funkcjonowanie administracji podatkowej uzależnione jest w istotnym stopniu od właściwego doboru kadry urzędniczej”48 z „odpowiednimi kwalifikacjami”49, autor niniejszego opracowania uważa, że radcowie skarbowi, którzy mogą w ramach szeroko rozumianych postępowań podatkowych - prowadzonych w trybie zarówno zwyczajnym, jak i nadzwyczajnym (pierwszo- i drugoinstancyjnych) - wydawać indywidualne akty podatkowe, powinni mieć ukończone studia wyższe o profilu prawno-podatkowym, takie jak: prawo, administracja, prawo podatkowe i rachunkowość, doradztwo podatkowe, prawo finansowe i skarbowość oraz podatki i doradztwo podatkowe, ponieważ tylko one odpowiednio przygotowują absolwentów do należytego stosowania norm prawa podatkowego (szczegółowego oraz procesowego $)^{50}$. Tezę tę - jak się wydaje - potwierdza przywoływany już dyrektor Departamentu Sytemu Podatkowego w Ministerstwie Finansów, wskazując, że intencją powołania radców skarbowych było „skupienie dla potrzeb funkcji orzeczniczej, pracowników o szczególnych kwalifikacjach, najwyższych kwalifikacjach w administracji skarbowej"51, tak aby docenić tych, „którzy mają szczególną wiedzę i charakteryzują się zaangażowaniem”52. Prawdziwy niepokój musi zatem budzić fakt, że na 120 radców skarbowych tylko 34 ma ukończone prawo; administrację 16, a co do innych preferowanych przez autora kierunków studiów - wynik jest zerowy (zob. tabela 1$)^{53}$. Natomiast pozostałe kierunki studiów ukończone przez radców skarbowych to: ekonomia - 28; zarządzanie i marketing - 8; finanse i bankowość - 4; ekonomika i organizacja produkcji - 4; zarządzanie - 3; organizacja i zarządzanie - 3; ekonomika i organizacja obrotu towarowego i usług - 2; budownictwo - 2; rolnictwo - 2; technologia żywności -1 ; geologia -1 ; towaroznawstwo -1 ; nauki polityczne -1 ;

50 I. Nowak, National..., s. 51; tenże Krajowa Administracja Skarbowa w liczbach, „Kazus Podatkowy” 2020, nr 4, s. 24-25; I. Nowak, Radca..., w druku.

51 Komisja Finansów Publicznych (nr 135).

52 Tamże.

53 Tamże. 
pedagogika specjalna - 1; ekonomika i organizacja przemysłu spożywczego - 1; ekonomika i organizacja transportu lądowego - 1; ekonomia społeczna -1 ; rachunkowość i finanse -1 ; historia -1 ; geografia -1 ; geodezja i kartografia - 1; melioracja wodna - 1; mechanika i budowa maszyn - 1 (zob. tabela 1). Warto także zauważyć, że np. w Izbie Administracji Skarbowej w Gdańsku, Wrocławiu i Zielonej Górze żaden z radców skarbowych nie ma ukończonych studiów o preferowanym przez autora profilu prawno-podatkowym. Natomiast wzorowo pod tym kątem wypada Izba Administracji Skarbowej w Białymstoku, gdzie na 8 radców skarbowych aż 7 ma ukończone prawo.

Prawodawca co do zasady nie unormował żadnych przesłanek, według których radcowie skarbowi ${ }^{54}$ mieliby być zatrudniani (powoływani), mimo że w trakcie prac legislacyjnych zwracano na to uwage $e^{55}$, ale była to niestety „oczywista próśb daremność”56. Również na poziomie Krajowej Administracji Skarbowej, a także Ministerstwa Finansów nie stworzono żadnych wytycznych dotyczących zasad zatrudniania (powoływania) radców skarbowych ${ }^{57}$, a na ocenie skuteczności ich pracy kończąc ${ }^{58}$. Tytułem przykładu: Minister Finansów, Funduszy i Polityki Regionalnej w piśmie z 14 grudnia 2020 r. podnosi, że nie dysponuje danymi w zakresie stanu zatrudnionych (pełniących służbę) radców skarbowych w izbach administracji skarbowej oraz podległych urzędach skarbowych i urzędach celnoskarbowych (wraz z delegaturami i oddziałami) ${ }^{59}$. Analogicznie w piśmie z 22 grudnia 2020 r. Minister Finansów, Funduszy i Polityki Regionalnej

54 I. Nowak, An officer..., s. 101; A. Krukowski, Komentarz do art. 148 u.k.a.s [w:] L. Bielecki, A. Gorgol (red.), Ustawa o Krajowej Administracji Skarbowej. Komentarz, Warszawa 2018, s. 508.

55 Szerzej opinia do ustawy - Przepisy wprowadzające ustawę o Krajowej Administracji Skarbowej (druk nr 313).

56 Fragment piosenki Jacka Kaczmarskiego, Kniazia Jaremy Nawrócenie, https://www.kaczmarski.art.pl/tworczosc/wiersze/kniazia-jaremy-nawrocenie/ (dostęp: 10.05.2021 r.).

57 Pismo Ministra Rozwoju i Finansów z dnia 26 kwietnia 2017 r., nr BMI1.0124.298.2017, http://www.skarbowcy.pl/blaster/extarticle.php?show=article\&article_id=25342 (dostęp: 01.05.2021 r.).

58 Pismo Ministra Finansów z dnia 23 sierpnia 2019 r., nr BMI1.0124.926.2019.

59 Pismo Ministra Finansów, Funduszy i Polityki Regionalnej z dnia 14 grudnia 2020 r., nr BMI1.0123.1795.2020. 
potwierdza, że nie zbiera danych dotyczących radców skarbowych, w tym także liczby osób zatrudnionych na poszczególnych stanowiskach w jednostkach organizacyjnych Krajowej Administracji Skarbowej, ponieważ danymi w tym zakresie dysponują poszczególne izby administracji skarbowej ${ }^{60}$.

„Lukę prawną” w powyższym zakresie „perfekcyjnie” wypełnili dyrektorzy izb administracji skarbowej. Stąd należy w tym miejscu poczynić kilka zastrzeżeń. Po pierwsze, niejednorodne były kryteria, jeśli chodzi o doświadczenie zawodowe (liczone w latach) w stosunku do powołanych radców skarbowych w poszczególnych jednostkach organizacyjnych Krajowej Administracji Skarbowej. Przykładowo: Izba Administracji Skarbowej we Wrocławiu - brak minimalnych okresów zatrudnienia ${ }^{61}$; Izba Administracji Skarbowej w Zielonej Górze - powyżej 3 lat ${ }^{62}$; Izba Administracji Skarbowej w Krakowie ${ }^{63}$ - minimum 5 lat; Izba Administracji Skarbowej w Białymstoku - minimum 5 lat ${ }^{64}$; Izba Administracji Skarbowej w Kielcach - 5,5 roku ${ }^{65}$; Izba Administracji Skarbowej w Warszawie - minimum 7 lat $^{66}$; Izba Administracji Skarbowej w Rzeszowie minimum 10 lat $^{67}$.

Po drugie, na stanowiska radców skarbowych nie były publikowane ogłoszenia o ich naborze w Biuletynie Informacji Publicznej Kancelarii Prezesa Rady Ministrów zgodnie z art. 28 ust. 1 in fine ustawy z 21 listo-

60 Pismo Ministra Finansów, Funduszy i Polityki Regionalnej z dnia 22 grudnia 2020 r., nr BMI1.0123.1882.2020; I. Nowak, Radca..., w druku.

61 Pismo Dyrektora IAS we Wrocławiu z dnia 5 kwietnia 2019 r., nr 0201-IWK.0150. 34.2019.

62 Pismo Dyrektora IAS w Zielonej Górze z dnia 9 kwietnia 2019 r., nr 0801-IWK.0150. 14.2019.

63 Pismo Dyrektora IAS w Krakowie z dnia 12 kwietnia 2019 r., nr 1201-IWK.0150.1. 15.2019.2.

64 Tamże oraz pismo Dyrektora IAS w Białymstoku z dnia 5 kwietnia 2019 r., nr 2001IWK.0150.16.2019.2.

65 Pismo Dyrektora IAS w Kielcach z dnia 11 kwietnia 2019 r., nr 2601-IWK.0150. 35.2019.

66 Pismo Dyrektora IAS w Warszawie z dnia 9 kwietnia 2019 r., nr 1401-IWK.0150. 23.2019.

67 Pismo Dyrektora IAS w Rzeszowie z dnia 14 kwietnia 2019 r., nr 1801-IWK.0150. 23.2019.5. 
pada 2008 r. o służbie cywilnej ${ }^{68}$. Tym samym uzasadnione, jak się wydaje, jest pytanie, jakimi przesłankami kierowali się dyrektorzy izb administracji skarbowej przy wyborze tych, a nie innych kandydatów, nolens volens spośród prawie 62 tysięcznego zasobu kadrowego Krajowej Administracji Skarbowej. I tak przykładowo:

a) Dyrektor Izby Administracji Skarbowej w Gdańsku podnosi, że „osoby zatrudnione na stanowisku radcy skarbowego to pracownicy o wysokim poziomie wiedzy z zakresu prawa podatkowego, rozpatrujący sprawy o wysokim stopniu trudności i złożoności. Z uwagi na wysokie predyspozycje zawodowe - umiejętność analitycznego i logicznego myślenia rozpatrują sprawy wymagające indywidualnego i kreatywnego podejścia do rozstrzygnięcia”“9 . Nie sposób jednak nie dostrzec, że na 8 radców skarbowych zatrudnionych w IAS w Gdańsku żaden z nich nie ma ukończonych kierunkowych studiów o profilu prawno-podatkowym. Wydanie zatem 444 rozstrzygnięć podatkowych (PIT - 235; VAT - 106; CIT - 102, podatki majątkowe -1) przez osoby, które ukończyły: zarządzanie; finanse i bankowość; ekonomikę i organizację produkcji; ekonomię społeczną; zarządzanie i marketing oraz ekonomikę i organizację transportu lądowego - może napawać bierne podmioty stosunku podatkowoprawnego prawdziwym niepokojem ${ }^{70}$.

b) Dyrektor Izby Administracji Skarbowej w Krakowie informuje, że bezpośredni przełożony, składając wniosek o powierzenie danemu pracownikowi stanowiska radcy skarbowego, kieruje się m.in. jego wszechstronną wiedzą, nie tylko w zakresie prawa podatkowego materialnego i procesowego, ale także w zakresie innych dziedzin pra-

68 Ustawa z 21 listopada 2008 r. o służbie cywilnej (tekst jedn. Dz.U. z 2021 r., poz. 1233 ze zm.).

69 Pismo Dyrektora IAS w Gdańsku z dnia 18 stycznia 2021 r., nr 2201-IWK.0150. 120.2020.13.

70 Nie można zatem podzielić poglądu T. Szymańskiego, który podnosi, iż „praktyka pokazała jednak, że rozstrzygnięcia podejmowane przez radców skarbowych zapadają sporadycznie" - T. Szymański, Komentarz do art. 13 o.p. [w:] A. Mariański (red.), Ordynacja podatkowa. Komentarz, Legalis/el. 2021. 
$\mathrm{wa}^{71}$. Jednakże powyższe zapowiedzi pozostały $\mathrm{w}$ sferze myślenia życzeniowego, ponieważ na 24 radców skarbowych aż 10 ma ukończone studia na kierunku: ekonomia - 6; zarzadzanie - 1 , zarządzanie i marketing -1 ; towaroznawstwo -1 ; pedagogika specjalna -1 .

c) Dyrektor Izby Administracji Skarbowej w Łodzi twierdzi, że „pracownicy zatrudnieni na stanowisku radcy skarbowego (...) są wyłaniani spośród kandydatów stanowiących filar wydziałów orzeczniczych”72, a ponadto są to osoby „z bardzo dużym doświadczeniem, kompetencjami i wiedzą zawodową pozwalającą na wykonywanie zadań z zakresu orzecznictwa"73. Nie można jednak również i w tym przypadku nie dostrzec, że 6 radców skarbowych z tejże jednostki organizacyjnej ma ukończone kierunkowe studia wyższe „niewpisujące” się w profil prawno-podatkowy (ekonomia - 4; finanse i bankowość - 1; zarządzanie i marketing - 1).

d) Dyrektor Izby Administracji Skarbowej w Poznaniu podnosi, że „na stanowisko radcy skarbowego zostały wyznaczone osoby (...) dysponujące szeroką wiedzą merytoryczną w zakresie prawa podatkowego"74. Trzeba jednak przy tym zastrzec, że jeśli chodzi o wykształcenie, to 5 radców skarbowych z tejże jednostki ma ukończone studia na kierunku: budownictwo - 2, ekonomika i organizacja produkcji 1 , zarządzanie i marketing -1 , ekonomia -1 , co raczej nie jest równoznaczne $\mathrm{z}$ posiadaniem szerokiej wiedzy, jeśli chodzi o prawo podatkowe...

e) Dyrektor Izby Administracji Skarbowej w Szczecinie zauważa, że informacje o wolnych stanowiskach radców skarbowych nie były rozpowszechniane „z uwagi na to, że na te stanowiska zostały awansowane osoby z długoletnim doświadczeniem zawodowym o wyso-

71 Pismo Dyrektora IAS w Krakowie z dnia 4 stycznia 2021, nr 1201-IWK.0150.1. 109.2020.11.

72 Pismo Dyrektora IAS w Łodzi z dnia 10 kwietnia 2019 r., nr 1001-IWK.0150.21.2019.

73 Pismo Dyrektora IAS w Łodzi z dnia 30 grudnia 2020 r., nr 1001-IWK.0150.105.2020.

74 Pismo Dyrektora IAS w Poznaniu z dnia 10 kwietnia 2019 r., nr 3001-IWK.0150. 24.2019. 
kim poziomie posiadanej wiedzy merytorycznej”"75. Ale czy rzeczywiście ekonomia jako kierunek studiów ukończony przez 7 radców skarbowych tutejszej izby gwarantuje wysoki poziom wiedzy z zakresu podatków?

f) Dyrektor Izby Administracji Skarbowej w Warszawie twierdzi, że „na stanowiska radców skarbowych nie były rozpisywane konkursy ze względu na szczególne wymagania związane z wykonywaniem czynności na tym stanowisku”76, m.in. posiadanie „wiedzy w zakresie wszystkich obowiązujących podatków”77 czy wykształcenia co najmniej wyższego (II stopnia) ${ }^{78}$. Odnotować w tym miejscu należy, że 15 radców skarbowych z Izby Administracji Skarbowej w Warszawie, legitymuje się ukończonymi studiami na kierunku: ekonomia - 5; zarządzanie i marketing - 2; rachunkowość i finanse - 1; organizacja i zarządzanie -1 ; rolnictwo -1 , historia -1 , geografia -1 , geodezja i kartografia - 1, melioracja wodna - 1, mechanika i budowa maszyn $-1^{79}$. Można jednak mieć uprawnione wątpliwości co do tego, czy ukończone kierunki studiów „zapewniają” nabycie wiedzy w zakresie wszystkich obowiązujących podatków.

g) Dyrektor Izby Administracji Skarbowej we Wrocławiu zauważa, że wyłanianie osób na stanowisko radcy skarbowego następuje co do zasady z uwzględnieniem posiadanego wykształcenia, doświadczenia oraz kwalifikacji zawodowych ${ }^{80}$. Biorąc powyższe pod uwagę, jest poniekąd zadziwiające, że 3 radców skarbowych ma ukończone studia wyższe o kierunku: technologia żywności; ekonomika i organiza-

75 Pismo Dyrektora IAS w Szczecinie z dnia 12 stycznia 2021 r., nr 3201-IWK.0150.2. 2021.2.

76 Pismo Dyrektora IAS w Warszawie z dnia 9 kwietnia 2019 r., nr 1401-IWK.0150. 23.2019.

77 Tamże.

78 Pismo Dyrektora IAS w Warszawie z dnia 20 stycznia 2021 r., nr 1401-IWK-2.0150. 8.2021.

79 Pismo Dyrektora IAS w Warszawie z dnia16 lutego 2021 r., nr 1401-IWK-2.0150. 13.2021.

80 Pismo Dyrektora IAS we Wrocławiu z dnia 5 kwietnia 2019 r., nr 0201-IWK.0150. 34.2019; pismo Dyrektora IAS we Wrocławiu z dnia 4 stycznia 2021 r., nr 0201IWK.0150.307.2020. 
cja przemysłu spożywczego oraz budownictwo. Warto także wskazać, że na stanowiska radców skarbowych w Izbie Administracji Skarbowej we Wrocławiu nie były „rozpisywane konkursy” ${ }^{81}$, gdyż jak zauważył jej dyrektor, przepisy prawne nie przewidują trybu konkursowego na etapie wyboru osób na stanowisko radcy skarbowego, a tym samym wykonywanie obowiązków na tym stanowisku rozpoczyna się z dniem jego powierzenia pracownikowi ${ }^{82}$.

h) Dyrektor Izby Administracji Skarbowej w Zielonej Górze podnosi, że osoby aktualnie zatrudnione na stanowisku radcy skarbowego otrzymały propozycje pracy w momencie powstawania Krajowej Administracji Skarbowej ${ }^{83}$. Trudno jednak przyjąć, że kierunkowe wykształcenie 4 radców skarbowych tam zatrudnionych jest „odpowiednio sprofilowane” do wydawania rozstrzygnięć podatkowych, ponieważ jest ono bez wątpienia niezwiązane ze stosowaniem prawa podatkowego (finanse i bankowość, zarządzanie i marketing, nauki polityczne, ekonomia i organizacja obrotu towarowego i usług).

Przeprowadzone badania empiryczne wykazały, że 58,33\% radców skarbowych nie posiada kierunkowego wykształcenia wyższego o profilu prawno-podatkowym ${ }^{84}$, właściwego do wymiaru, poboru i egzekucji danin publicznoprawnych $^{85}$. Tym samym wydawanie przez nich „poprawnych merytorycznie” indywidualnych aktów podatkowych co do zasady w za-

81 Pismo Dyrektora IAS we Wrocławiu z dnia 5 kwietnia 2019 r., nr 0201-IWK.0150. 34.2019.

82 Pismo Dyrektora IAS we Wrocławiu z dnia 18 styczeń 2021 r., nr 0201-IWK.0150. 307.2020.

83 Pismo Dyrektora IAS w Zielonej Górze dnia 18 stycznia 2021 r., nr 0801-IWK.0150. 1.2021.

84 Przeprowadzone w latach 2002-2005 badania empiryczne wśród 8 urzędów kontroli skarbowej wykazały że wskaźnik osób zatrudnionych na stanowiskach merytorycznych legitymujących się wykształceniem innym niż wyższe prawnicze lub ekonomiczne był na poziomie $60 \%$ - E. Ruśkowski, Główne problemy reformy administracji skarbowej (z uwzględnieniem projektów ustawy o KAS i ustawy wprowadzajq̨cej) [w:] Z. Gilowska, H. Izdebski, K. Raczkowski (red.), Efektywna administracja skarbowa, t. 1 (w serii: Krajowa Administracja Skarbowa), Warszawa 2007, s. 93.

85 Faktem jest, że niektórzy z radców skarbowych ukończyli także studia podyplomowe z zakresu prawa podatkowego, jednakże ta forma „podnoszenia swoich kwalifikacji” zdaniem autora - nie uzupełni ukończonych studiów I i II stopnia sprofilowanych pod kątem programu kształcenia z zakresu podatkowoprawnego. 
kresie podatku od towarów i usług, podatku dochodowego od osób fizycznych oraz podatku dochodowego od osób prawnych, przy permanentnych nowelizacjach i skomplikowaniu tych ostatnich, wydaje się mało prawdopodobne. Należy przecież pamiętać, że w powyższych daninach dochodzi najczęściej do sporów ${ }^{86}$, dotyczących prawidłowo określonych (ustalonych) wysokości należności podatkowoprawnych ${ }^{87}$, przez co preferowane przez autora wykształcenie ma w tym przypadku fundamentalne znaczenie. Innymi słowy, w jednostkach organizacyjnych Krajowej Administracji Skarbowej powinni znaleźć zatrudnienie „fachowcy, a nie amatorzy prawa”88 i podatków, ponieważ realizacja zadań z zakresu administracji podatkowej (skarbowej) przez osoby, których „predyspozycje” nie pozwalają „osiągnąć zamierzonego celu jest marnowaniem środków i tym samym podwyższa koszty poboru podatków, a więc jest sprzeczne z zasadą taniości opodatkowania"89.

Po trzecie, według dyrektora Departamentu Systemu Podatkowego w Ministerstwie Finansów „liczba radców skarbowych uzależniona jest od zakresu orzecznictwa w urzędzie skarbowym. Wielkość urzędów skarbowych jest bardzo zróżnicowana, liczba wydawanych decyzji również jest zróżnicowana, więc to będzie w każdym urzędzie dopasowane do zadań. Ma to być związane z zadaniami”"90. Dla porządku godzi się wspomnieć, że większość radców skarbowych jest zatrudniona w izbach administracji skarbowej i urzędach celno-skarbowych, a nie urzędach skarbowych. Po-

86 W. Nykiel, O potrzebie równowagi między uprawnieniami i obowiq̨zkami podatnika oraz organów podatkowych, „Prawo i Podatki” 2005, nr 12, s. 25-28.

87 Zob. T. Dębowska-Romanowska, Uwagi o sposobie definiowania przedmiotu i podstawy opodatkowania z punktu widzenia obliczenia prawidłowej (jednej i jedynej) kwoty podatku [w:] B. Brzeziński, J. Głuchowski, C. Kosikowski, R. Mastalski (red.), Księga pamiq̨tkowa ku czci Profesora Apoloniusza Kosteckiego. Studia z dziedziny prawa podatkowego, Toruń 1998; W. Nykiel, Prawo do zapłaty podatku w wysokości wynikajq̨cej z przepisów prawa, „Prawo i Podatki” 2008, nr 1, s. 1-2; W. Nykiel, M. Sęk, Projekt ustawy Karta Praw Podatnika z uzasadnieniem, „Kwartalnik Prawa Podatkowego" 2018, nr 1, s. 105-127.

88 Tak J. Małecki, Recenzja cz. II pt. Kontrola stosowania prawa podatkowego w Polsce [w:] E. Ruśkowski (red.), Kontrola..., s. 151.

89 M. Staniszewski, Zasada efektywności opodatkowania w działalności administracji podatkowej w Polsce, Jarocin 2007, s. 149.

90 Komisja Finansów Publicznych (nr 135). 
nadto z przeprowadzonych badań empirycznych bezspornie wynika „dysfunkcyjność”, jeśli chodzi o liczbę wydanych w okresie od 1 marca 2017 do 31 grudnia 2020 r. przez radców skarbowych decyzji podatkowych w poszczególnych jednostkach organizacyjnych Krajowej Administracji Skarbowej. Przykładowo:

a) 11 radców skarbowych z Izby Administracji Skarbowej w Łodzi wydało 335 indywidualnych aktów podatkowych ${ }^{91}$ (średnio 30,45 na osobę);

b) 8 radców skarbowych z Izby Administracji Skarbowej w Białymstoku wydało 82 indywidualne akty podatkowe ${ }^{92}$ (średnio 10,25 na osobę);

c) 8 radców skarbowych z Izby Administracji Skarbowej w Gdańsku wydało 444 indywidualne akty podatkowe ${ }^{93}$ (średnio 55,5 na osobę);

d) 8 radców skarbowych z Izby Administracji Skarbowej w Poznaniu wydało 274 indywidualne akty podatkowe ${ }^{94}$ (średnio 34,25 na osobę);

e) 5 radców skarbowych z Izby Administracji Skarbowej w Kielcach ${ }^{95}$ wydało 77 indywidualnych aktów podatkowych ${ }^{96}$ (średnio 15,4 na osobę);

f) 5 radców skarbowych z Izby Administracji Skarbowej w Rzeszowie $^{97}$ wydało 678 indywidualnych aktów podatkowych ${ }^{98}$ (średnio 135,6 na osobę);

g) 4 radców skarbowych z Izby Administracji Skarbowej w Zielonej Górze $^{99}$ wydało 17 indywidualnych aktów podatkowych ${ }^{100}$ (średnio 4,25 na osobę);

91 Pismo Dyrektora IAS w Łodzi z dnia 30 grudnia 2020 r., nr 1001-IWK.0150.105.2020.

92 Pismo Dyrektora IAS w Białymstoku z dnia 30 grudnia 2020 r., nr 2001-IWK.0150. 100.2020.2 oraz z dnia 4 stycznia 2021 r., nr 2001-IWK.0150.1.2021.2.

93 Pismo Dyrektora IAS w Gdańsku z dnia 11 stycznia 2021 r., nr 2201-IWK.0150. 120.2020.

94 Pismo Dyrektora IAS w Poznaniu z dnia 11 stycznia 2021 r., nr 3001-IWK.0150. 145.2020.

95 Wliczając radców skarbowych ze Świętokrzyskiego Urzędu Celno-Skarbowego w Kielcach.

96 Dane bez drugiego półrocza 2020 r. - pismo Dyrektora IAS w Kielcach z dnia 4 stycznia 2021 r., nr 2601-IWK.0150.136.2020.

97 Wliczając radców skarbowych z Podkarpackiego Urzędu Celno-Skarbowego w Przemyślu.

98 Pismo Dyrektora IAS w Rzeszowie z dnia 30 grudnia 2020 r., nr 1801IWK.0150.109.2020 oraz Naczelnika Podkarpackiego Urzędu Celno-Skarbowego z dnia 25 stycznia 2021 r., nr 408000-408000-CWW.0150.1.2021. 
h) 3 radców skarbowych z Izby Administracji Skarbowej w Bydgoszczy wydało 4 indywidualne akty podatkowe ${ }^{101}$ (średnio 1,33 na osobę);

i) 3 radców skarbowych z Izby Administracji Skarbowej we Wrocławiu - nie wydało żadnych indywidualnych aktów podatkowych, ponieważ nie zostali do tego upoważnieni ${ }^{102}$.

Tabela 1. Radcowie skarbowi zatrudnieni (powołani) w jednostkach organizacyjnych Krajowej Administracji Skarbowej w liczbach (stan na 31 grudnia 2020 r.).

\begin{tabular}{|c|c|c|c|c|c|}
\hline $\begin{array}{l}\text { Izba Admini- } \\
\text { stracji Skar- } \\
\text { bowej } \\
\text { wraz z pod- } \\
\text { ległymi } \\
\text { jednostkami }\end{array}$ & $\begin{array}{c}\text { Liczba } \\
\text { radców } \\
\text { skarbowych }\end{array}$ & $\begin{array}{l}\text { Kierunki stu- } \\
\text { diów ukończone } \\
\text { przez radców } \\
\text { skarbowych }\end{array}$ & $\begin{array}{l}\text { Studia pody- } \\
\text { plomowe ukoń- } \\
\text { czone przez } \\
\text { radców skarbo- } \\
\text { wych (według } \\
\text { liczby osób } \\
\text { i nazwy) }\end{array}$ & $\begin{array}{c}\text { Liczba } \\
\text { radców } \\
\text { skarbowych, } \\
\text { którzy } \\
\text { wcześniej } \\
\text { pracowali na } \\
\text { stanowisku } \\
\text { inspektora } \\
\text { kontroli } \\
\text { skarbowej } \\
\end{array}$ & $\begin{array}{c}\text { Decyzje wyda- } \\
\text { ne przez radców } \\
\text { skarbowych } \\
\text { w latach } 2017- \\
2020 \\
\text { (według liczby } \\
\text { i nazw podatku) }\end{array}$ \\
\hline \multirow[t]{2}{*}{ Białystok } & \multirow{2}{*}{$\begin{array}{c}8 \\
\text { (4 kobiety } \\
\text { i } 4 \text { męż- } \\
\text { czyzn) }\end{array}$} & prawo -7 & \multirow{2}{*}{$\begin{array}{l}\text { 5: (brak danych } \\
\text { co do nazwy) }\end{array}$} & \multirow[t]{2}{*}{4} & \multirow{2}{*}{$\begin{array}{l}\text { 82: VAT - 52; } \\
\text { PIT - 26; } \\
\text { CIT - 2; } \\
\text { akcyza - } 2\end{array}$} \\
\hline & & $\begin{array}{l}\text { zarządzanie } \\
\text { i marketing }-1\end{array}$ & & & \\
\hline \multirow{3}{*}{ Bydgoszcz } & \multirow{3}{*}{$\begin{array}{c}3 \\
\text { (2 kobiety } \\
\text { i } 1 \text { mężczy- } \\
\text { zna) }\end{array}$} & prawo - 1 & \multirow{3}{*}{$\begin{array}{l}\text { 2: (prawo po- } \\
\text { datkowe UE - } \\
\text { 2), rachunko- } \\
\text { wość przedsię- } \\
\text { biorstw - 1) }\end{array}$} & \multirow{3}{*}{3} & \multirow{3}{*}{$\begin{array}{l}\text { 4: tylko Kujaw- } \\
\text { sko-Pomorski } \\
\text { Urząd Celno- } \\
\text { Skarbowy w } \\
\text { Toruniu } \\
\text { (VAT - 3; } \\
\text { CIT - 1) }\end{array}$} \\
\hline & & $\begin{array}{l}\text { ekonomika i } \\
\text { organizacja } \\
\text { produkcji - } 1 \\
\end{array}$ & & & \\
\hline & & rolnictwo - 1 & & & \\
\hline \multirow{3}{*}{ Gdańsk } & \multirow{3}{*}{$\begin{array}{c}8 \\
\text { (tylko } \\
\text { kobiety) }\end{array}$} & zarządzanie - 2 & \multirow{3}{*}{$\begin{array}{l}\text { 4: (rachunko- } \\
\text { wość - } 3 \text {, prawo } \\
\text { podatkowe }-1 \text {, } \\
\text { rachunkowość i } \\
\text { finanse - } 1\end{array}$} & \multirow{3}{*}{0} & \multirow{3}{*}{$\begin{array}{l}\text { 444: VAT - } \\
\text { 106; PIT - 235; } \\
\text { CIT - 102; } \\
\text { podatki mająt- } \\
\text { kowe - } 1\end{array}$} \\
\hline & & $\begin{array}{l}\text { finanse i ban- } \\
\text { kowość - } 2\end{array}$ & & & \\
\hline & & ekonomika i & & & \\
\hline
\end{tabular}

99 Z miejscem świadczenia pracy w Lubuskim Urzędzie Celno-Skarbowy w Gorzowie Wielkopolskim.

100 Pismo Dyrektora IAS w Zielonej Górze z dnia 18 stycznia 2021 r., nr 0801IWK.0150.1.2021 oraz Naczelnika Lubuskiego Urzędu Celno-Skarbowego w Gorzowie Wielkopolskim z dnia 28 stycznia 2021 r., nr 418000-CWW-1.0150.1.2021.

101 Pismo Dyrektora IAS w Bydgoszczy z dnia 7 stycznia 2021 r., nr 0401IWK.0150.98.2020.6 oraz Naczelnika Kujawsko-Pomorskiego Urzędu CelnoSkarbowego w Toruniu z dnia 19 stycznia 2021 r., nr 438000-CWW.0150.1.2021.2.

102 Pismo Dyrektora IAS we Wrocławiu z dnia 4 styczeń 2021 r., 0201-IWK.0150. 307.2020. 


\begin{tabular}{|c|c|c|c|c|c|}
\hline & & $\begin{array}{l}\text { organizacja } \\
\text { produkcji - } 1\end{array}$ & & & \\
\hline & & $\begin{array}{l}\text { ekonomia } \\
\text { społeczna - } 1\end{array}$ & & & \\
\hline & & $\begin{array}{l}\text { zarządzanie i } \\
\text { marketing - } 1\end{array}$ & & & \\
\hline & & $\begin{array}{l}\text { ekonomika i } \\
\text { organizacja } \\
\text { transportu } \\
\text { lądowego - } 1\end{array}$ & & & \\
\hline Katowice & $\begin{array}{c}\text { brak rad- } \\
\text { ców skar- } \\
\text { bowych }\end{array}$ & $\begin{array}{l}\text { brak radców } \\
\text { skarbowych }\end{array}$ & $\begin{array}{l}\text { brak radców } \\
\text { skarbowych }\end{array}$ & $\begin{array}{l}\text { brak radców } \\
\text { skarbowych }\end{array}$ & $\begin{array}{l}\text { brak radców } \\
\text { skarbowych }\end{array}$ \\
\hline \multirow{3}{*}{ Kielce } & \multirow{3}{*}{$\begin{array}{c}5 \\
\text { (4 kobiety } \\
\text { i } 1 \text { mężczy- } \\
\text { zna) }\end{array}$} & ekonomia - 3 & \multirow{3}{*}{$\begin{array}{l}\text { 1: (rachunko- } \\
\text { wość i finanse) }\end{array}$} & \multirow{3}{*}{3} & \multirow{3}{*}{$\begin{array}{l}\text { 77: bez II } \\
\text { półrocza 2020 r. } \\
\text { (VAT - 58; } \\
\text { PIT - 14; } \\
\text { CIT - 2; } \\
\text { akcyza - 1; } \\
\text { spadki i daro- } \\
\text { wizny - 1) }\end{array}$} \\
\hline & & $\begin{array}{l}\text { administracja - } \\
1\end{array}$ & & & \\
\hline & & geologia -1 & & & \\
\hline \multirow[t]{7}{*}{ Kraków } & \multirow{7}{*}{$\begin{array}{l}\quad 24 \\
\text { (23 kobiety } \\
\text { i } 1 \text { mężczy- } \\
\text { zna) }\end{array}$} & prawo -10 & \multirow{7}{*}{$\begin{array}{l}\text { 6: (rachunko- } \\
\text { wość i finanse - } \\
\text { 3; zarządzanie i } \\
\text { finanse - 1; } \\
\text { administracja } \\
\text { publiczna - } 1 \text {; } \\
\text { public relations } \\
-1 \text { ) }\end{array}$} & \multirow{7}{*}{1} & \multirow{7}{*}{ brak danych } \\
\hline & & ekonomia -6 & & & \\
\hline & & $\begin{array}{l}\text { administracja - } \\
4\end{array}$ & & & \\
\hline & & zarzadzanie - 1 & & & \\
\hline & & $\begin{array}{l}\text { zarządzanie i } \\
\text { marketing - } 1\end{array}$ & & & \\
\hline & & $\begin{array}{l}\text { towaroznawstwo } \\
-1\end{array}$ & & & \\
\hline & & $\begin{array}{l}\text { pedagogika } \\
\text { specjalna - } 1\end{array}$ & & & \\
\hline \multirow{3}{*}{ Lublin } & \multirow{3}{*}{$\begin{array}{c}5 \\
\text { (3 kobiety } \\
\text { i } 2 \text { męż- } \\
\text { czyzn) }\end{array}$} & ekonomia - 2 & \multirow{3}{*}{$\begin{array}{l}\text { 3: (skarbowość } \\
\text { - } 1 \text {; egzekucja } \\
\text { administracyjna } \\
-1 \text {; rachunko- } \\
\text { wość - 1) }\end{array}$} & \multirow{3}{*}{0} & \multirow{3}{*}{$\begin{array}{l}\text { brak danych } \\
\text { (wszyscy } \\
\text { radcowie skar- } \\
\text { bowi powołani } \\
\text { zostali } \\
\text { w } 2020 \text { r.) }\end{array}$} \\
\hline & & $\begin{array}{l}\text { organizacja i } \\
\text { zarządzanie - } 2\end{array}$ & & & \\
\hline & & prawo -1 & & & \\
\hline Łódź & $\begin{array}{c}11 \\
\text { (8 kobiet } \\
\text { i } 3 \text { męż- } \\
\text { czyzn) }\end{array}$ & $\begin{array}{l}\text { administracja - } \\
4\end{array}$ & $\begin{array}{l}\text { 5: (prawo po- } \\
\text { datkowe - 1; } \\
\text { rachunkowość i } \\
\text { finanse - } 1 \text {; }\end{array}$ & 4 & $\begin{array}{l}\text { 335: VAT - } \\
\text { 151; PIT - 44; } \\
\text { CIT - 19; } \\
\text { akcyza - 21; }\end{array}$ \\
\hline
\end{tabular}




\begin{tabular}{|c|c|c|c|c|c|}
\hline & & ekonomia - 4 & \multirow{4}{*}{$\begin{array}{l}\text { przeciwdziałanie } \\
\text { agresywnemu } \\
\text { planowaniu } \\
\text { podatkowemu - } \\
\text { 1; europejskie } \\
\text { prawo gospo- } \\
\text { darcze i marke- } \\
\text { ting - 1; fundu- } \\
\text { sze Unii Euro- } \\
\text { pejskiej - 1) }\end{array}$} & & \multirow[t]{4}{*}{$\begin{array}{l}\text { inne podatki - } \\
46\end{array}$} \\
\hline & & $\begin{array}{l}\text { finanse i ban- } \\
\text { kowość - } 1\end{array}$ & & & \\
\hline & & $\begin{array}{l}\text { zarządzanie i } \\
\text { marketing - } 1\end{array}$ & & & \\
\hline & & prawo -1 & & & \\
\hline Olsztyn & $\begin{array}{l}\text { brak rad- } \\
\text { ców skar- } \\
\text { bowych }\end{array}$ & $\begin{array}{l}\text { brak radców } \\
\text { skarbowych }\end{array}$ & $\begin{array}{l}\text { brak radców } \\
\text { skarbowych }\end{array}$ & $\begin{array}{l}\text { brak radców } \\
\text { skarbowych }\end{array}$ & $\begin{array}{l}\text { brak radców } \\
\text { skarbowych }\end{array}$ \\
\hline Opole & $\begin{array}{l}\text { brak rad- } \\
\text { ców skar- } \\
\text { bowych }\end{array}$ & $\begin{array}{l}\text { brak radców } \\
\text { skarbowych }\end{array}$ & $\begin{array}{l}\text { brak radców } \\
\text { skarbowych }\end{array}$ & $\begin{array}{l}\text { brak radców } \\
\text { skarbowych }\end{array}$ & $\begin{array}{l}\text { brak radców } \\
\text { skarbowych }\end{array}$ \\
\hline \multirow{5}{*}{ Poznań } & \multirow{5}{*}{$\begin{array}{c}8 \\
\text { (6 kobiet i } 2 \\
\text { mężczyzn) }\end{array}$} & prawo -3 & \multirow{5}{*}{$\begin{array}{l}\text { 6: (prawo podat- } \\
\text { kowe-2; ra- } \\
\text { chunkowość - 1; } \\
\text { bezpieczeństwo i } \\
\text { higiena pracy - 1; } \\
\text { finanse - 1; audyt } \\
\text { i kontrola we- } \\
\text { wnętrzna w } \\
\text { gospodarce i } \\
\text { administracji - 1) }\end{array}$} & \multirow{5}{*}{1} & \multirow{5}{*}{$\begin{array}{l}274 \text { (tylko w } \\
\text { zakresie VAT) }\end{array}$} \\
\hline & & budownictwo - 2 & & & \\
\hline & & $\begin{array}{l}\text { ekonomika i } \\
\text { organizacja } \\
\text { produkcji - } 1\end{array}$ & & & \\
\hline & & $\begin{array}{l}\text { zarządzanie i } \\
\text { marketing - } 1\end{array}$ & & & \\
\hline & & ekonomia - 1 & & & \\
\hline \multirow[b]{4}{*}{ Rzeszów } & \multirow[b]{4}{*}{$\begin{array}{c}5 \\
\text { (1 kobieta } \\
\text { i } 4 \text { męż- } \\
\text { czyzn) }\end{array}$} & prawo -3 & & \multirow[b]{4}{*}{3} & \multirow{4}{*}{$\begin{array}{l}452 \text { (tylko w } \\
\text { samej IAS w } \\
\text { zakresie VAT, } \\
\text { PIT, CIT - brak } \\
\text { doprecyzowania } \\
\text { wg podatków) } \\
\text { 226: tylko } \\
\text { Podkarpacki } \\
\text { Urząd Celno- } \\
\text { Skarbowy w } \\
\text { Przemyślu } \\
\text { (VAT - 175; } \\
\text { PIT - 35; } \\
\text { CIT - 11; } \\
\text { akcyza - 4; } \\
\text { spadki i daro- } \\
\text { wizny - 1) }\end{array}$} \\
\hline & & administracja - 1 & & & \\
\hline & & $\begin{array}{l}\text { ekonomika i } \\
\text { organizacja } \\
\text { produkcji - } 1\end{array}$ & & & \\
\hline & & $\begin{array}{l}\text { ekonomia } \\
\text { i organizacja } \\
\text { obrotu towaro- } \\
\text { wego i usług - } 1\end{array}$ & brak danych & & \\
\hline
\end{tabular}




\begin{tabular}{|c|c|c|c|c|c|}
\hline \multirow[t]{2}{*}{ Szczecin } & \multirow{2}{*}{$\begin{array}{c}10 \\
\text { (8 kobiet } \\
\text { i } 2 \text { męż- } \\
\text { czyzn) }\end{array}$} & $\begin{array}{l}\text { ekonomia - } 7 \\
\text { administracja - } \\
2 \\
\end{array}$ & \multirow{2}{*}{$\begin{array}{l}\text { 4: (skarbowość } \\
-2 \text {; skarbowość } \\
\text { dla kadry kie- } \\
\text { rowniczej } \\
\text { organów skar- } \\
\text { bowych - } 1 \text {; } \\
\text { informatyka w } \\
\text { biznesie - 1) }\end{array}$} & \multirow{2}{*}{4} & \multirow{2}{*}{$\begin{array}{l}\text { 106: VAT - 72; } \\
\text { PIT wraz } \\
\text { z CIT - 31; } \\
\text { akcyza - } 3\end{array}$} \\
\hline & & prawo - 1 & & & \\
\hline \multirow{11}{*}{ Warszawa } & \multirow{11}{*}{$\begin{array}{c}26 \\
\text { (19 kobiet } \\
\text { i } 7 \text { męż- } \\
\text { czyzn) }\end{array}$} & prawo -7 & \multirow{11}{*}{$\begin{array}{l}\text { 11: (brak infor- } \\
\text { macji o na- } \\
\text { zwach) }\end{array}$} & \multirow{11}{*}{1} & \multirow{11}{*}{$\begin{array}{l}812 \text { (tylko w } \\
\text { samej IAS) }\end{array}$} \\
\hline & & $\begin{array}{l}\text { ekonomia }-5 \\
\text { administracja - } \\
4\end{array}$ & & & \\
\hline & & $\begin{array}{l}\text { zarządzanie i } \\
\text { marketing - } 2\end{array}$ & & & \\
\hline & & $\begin{array}{l}\text { rachunkowość i } \\
\text { finanse }-1\end{array}$ & & & \\
\hline & & $\begin{array}{l}\text { organizacja i } \\
\text { zarządzenie - } 1 \\
\end{array}$ & & & \\
\hline & & rolnictwo -1 & & & \\
\hline & & historia - 1 & & & \\
\hline & & geografia - 1 & & & \\
\hline & & $\begin{array}{l}\text { geodezja i } \\
\text { kartografia - } 1\end{array}$ & & & \\
\hline & & $\begin{array}{l}\text { melioracja } \\
\text { wodna }-1\end{array}$ & & & \\
\hline & & $\begin{array}{l}\text { mechanika i } \\
\text { budowa maszyn } \\
-1\end{array}$ & & & \\
\hline \multirow{3}{*}{ Wrocław } & \multirow{3}{*}{$\begin{array}{c}3 \\
\text { (1 kobieta } \\
\text { i } 2 \text { męż- } \\
\text { czyzn) }\end{array}$} & $\begin{array}{l}\text { technologia } \\
\text { żywności - } 1\end{array}$ & \multirow{3}{*}{$\begin{array}{l}\text { 2: (prawo po- } \\
\text { datkowe Unii } \\
\text { Europejskiej - } \\
\text { 1; prawo gospo- } \\
\text { darcze i han- } \\
\text { dlowe - 1) }\end{array}$} & \multirow{3}{*}{2} & \multirow{3}{*}{$\begin{array}{l}\text { radcowie skar- } \\
\text { bowi nie wyda- } \\
\text { ją decyzji w } \\
\text { imieniu organu } \\
\text { podatkowego }\end{array}$} \\
\hline & & $\begin{array}{l}\text { ekonomika i } \\
\text { organizacja } \\
\text { przemysłu } \\
\text { spożywczego - } \\
1\end{array}$ & & & \\
\hline & & budownictwo - 1 & & & \\
\hline \multirow{4}{*}{ Zielona Góra } & \multirow{4}{*}{$\begin{array}{c}4 \\
\text { (3 kobiety } \\
\text { i } 1 \text { mężczy- } \\
\text { zna) }\end{array}$} & $\begin{array}{l}\text { finanse i ban- } \\
\text { kowość - } 1\end{array}$ & \multirow{4}{*}{$\begin{array}{l}\text { 2: (rachunko- } \\
\text { wość i finanse) }\end{array}$} & \multirow{4}{*}{4} & \multirow{4}{*}{$\begin{array}{l}\text { 17: tylko Lubu- } \\
\text { ski Urząd } \\
\text { Celno- } \\
\text { Skarbowy w } \\
\text { Gorzowie- } \\
\text { Wielkopolskim } \\
\text { (VAT - 11; } \\
\text { PIT - 2; } \\
\text { CIT - 4) }\end{array}$} \\
\hline & & $\begin{array}{l}\text { zarządzanie i } \\
\text { marketing - } 1\end{array}$ & & & \\
\hline & & $\begin{array}{l}\text { nauki polityczne } \\
-1\end{array}$ & & & \\
\hline & & $\begin{array}{l}\text { ekonomia i } \\
\text { organizacja } \\
\text { obrotu towaro- } \\
\text { wego i usług - } 1\end{array}$ & & & \\
\hline
\end{tabular}

Źródło: Opracowanie własne na podstawie danych uzyskanych od dyrektorów izb administracji skarbowej w trybie ustawy o dostępie do informacji publicznej. 


\section{Wynagrodzenie radców skarbowych}

Biorąc pod uwagę medianę wynagrodzeń brutto radców skarbowych do analogicznej wartości członków korpusu służby cywilnej, którzy nie zajmują tegoż „eksponowanego” urzędniczego stanowiska, wynika, że jest ona wyższa o ok. trzy tysiące złotych brutto (szerzej tabela 2 i 3). Przykładowo, mediana wynagrodzenia radców skarbowych na 31 grudnia 2020 r. w: Izbie Administracji Skarbowej we Wrocławiu wynosi 10 930,27 zł; Izbie Administracji Skarbowej w Rzeszowie - 9547,96 zł ${ }^{103}$; Izbie Administracji Skarbowej w Bydgoszczy - 8823,72 zł; Izbie Administracji Skarbowej w Kielcach - 8751,34 zł. Natomiast najniższa mediana wynagrodzenia radców skarbowych jest w Izbie Administracji Skarbowej w Szczecinie - 7534,77 zł.

Wyższe wynagrodzenie radców skarbowych zapewne wynika z dodatku orzeczniczego, który zgodnie z art. 148 ust. 1 pkt 3 u.k.a.s. przysługuje osobie zatrudnionej w jednostce organizacyjnej Krajowej Administracji Skarbowej oraz funkcjonariuszowi przysługuje odpowiednio do wynagrodzenia albo uposażenia dodatek orzeczniczy w wysokości do 50\% wynagrodzenia zasadniczego osoby zatrudnionej w jednostce organizacyjnej Krajowej Administracji Skarbowej albo uposażenia zasadniczego funkcjonariusza na stanowisku radcy skarbowego za wykonywanie czynności organu, o których mowa w art. 13 § 2c o.p. ${ }^{104}$. Bez wątpienia jest to „dysfunkcyjne” rozwiązanie, m.in. ze względu na brak jakiejkolwiek „ścieżki zawodowej”105 dla członków korpusu służby cywilnej oraz funkcjonariuszy Służby Celno-Skarbowej, którzy mogliby aplikować na

103 Mediana uposażeń brutto jedynego funkcjonariusza Służby Celno-Skarbowej, pełniącego służbę na stanowisku radcy skarbowego w Podkarpackim Urzędzie CelnoSkarbowym w Przemyślu (IAS w Rzeszowie), wynosi 8221,47 zł - pismo Dyrektora IAS w Rzeszowie z dnia 30 grudnia 2020 r., nr 1801-IWK.0150.109.2020 oraz pismo Dyrektora IAS w Rzeszowie z dnia 3 marca 2021, nr 1801-IWK.0150.8.2021.

104 Zob. rozporządzenie Ministra Rozwoju i Finansów z dnia 26 kwietnia 2017 r. w sprawie dodatku orzeczniczego na stanowisku radcy skarbowego (Dz.U. z 2017 r. poz. 863) oraz rozporządzenie Ministra Finansów w sprawie dodatku orzeczniczego na stanowisku radcy skarbowego z dnia 23 grudnia 2019 r. (Dz.U. z 2019 r. poz. 2539).

105 https://www.prawo.pl/kadry/funkcjonariusze-sluzb-oddelegowani-albo-emerytowanizajmuja,506164.html (dostęp: 04.07.2021 r.). 
stanowisko radcy skarbowego, ale nie mogą tego uczynić, ponieważ nie zostało to prawnie określone, a jedynie pozostawione w dyskrecjonalnym uznaniu dyrektorów izb administracji skarbowej. Trudno zatem przyjąć za wiarygodne podziękowania ze strony Szefa Krajowej Administracji Skarbowej za wszystkie sukcesy, które „nie byłyby możliwe bez zaangażowania, profesjonalizmu, odpowiedzialnej postawy kierownictwa, pracowników i funkcjonariuszy jednostek KAS” ${ }^{106}$. I co tu można rzec na takie dictum? Chyba tylko tyle, że konsolidacja administracji danin publicznych przyniosła totalną destrukcję w zakresie kadrowym, co do zasady z powodu zastosowania tzw. opcji zerowej, ucywilnień funkcjonariuszy celnych $^{107}$ i mnóstwa innych zamierzonych działań, które tylko pogłębiły brak poczucia stabilizacji zawodowej wśród pozostałych pracowników i funkcjonariuszy ${ }^{108}$, a w końcu doprowadziły też do frustracji spowodowanej brakiem jakiejkolwiek wizji profesjonalnego działania ze strony prawodawcy (ale także organów Krajowej Administracji Skarbowej) ${ }^{109}$.

Reasumując, wynagrodzenia radców skarbowych są bez wątpienia o czym szczegółowo traktuje tabela 2 - ustalone nolens volens jak przystało na „elitę” Krajowej Administracji Skarbowej. Każdy zapewne członek korpusu służby cywilnej oraz funkcjonariusz Służby CelnoSkarbowej przystałby ad hoc na takie warunki. Tylko czy rzeczywiście wybór - tych, a nie innych stricte kandydatów na radców skarbowych jednoosobowo i dyskrecjonalnie przez dyrektorów izb administracji skarbowych został dokonany spośród najlepszych osób, zasługujących na tak wysokie „apanaże”? Niestety, autor niniejszego opracowania, na podstawie przeprowadzonych badań, ma w tym zakresie uzasadnione wątpliwości.

106 Fragment listu Szefa KAS z okazji XVII edycji rankingu urzędów skarbowych i izb administracji skarbowej, https://www.skarbowcy.pl/blaster/extarticle.php?show=article \&article_id=27793 (dostęp: 07.05.2021 r.).

107 E. Ura, „Ucywilnianie” dotychczasowych stosunków służbowych funkcjonariuszy celnych $w$ zwiqzzu z reformq administracji celno-skarbowej - w kontekście zasady praworzq̨dności, „Przegląd Prawa i Administracji” 2018, nr 114, s. 255 i n.; I. Nowak, Funkcjonariusze..., s. 37 i n.; A. Halicki, Służba w służbie celno-skarbowej, Szczecin 2021, passim.

108 Zob. E. Ruśkowski, Główne..., s. 62; tenże Kontrola..., s. 134-135.

109 I. Nowak, Krajowa Administracja Skarbowa w świetle..., s. 49 i n. 
Ireneusz Nowak

Tabela 2. Wynagrodzenie brutto PLN radców skarbowych (stan na 31 grudnia 2020 r.).

\begin{tabular}{|l|l|l|}
\hline \multicolumn{1}{|c|}{$\begin{array}{c}\text { Izba Administracji } \\
\text { Skarbowej }\end{array}$} & \multicolumn{1}{|c|}{ Średnia } & \multicolumn{1}{c|}{ Mediana } \\
\hline Białystok & 8268,60 & 8369,21 \\
\hline Bydgoszcz & 9210,31 & 8823,72 \\
\hline Gdańsk & 8133,93 & 7998,28 \\
\hline Katowice & brak radców skarbowych & brak radców skarbowych \\
\hline Kielce & 8222,38 & 8751,34 \\
\hline Kraków & 8137,01 & 7911,63 \\
\hline Lublin & 7263,15 & 7702,08 \\
\hline Łódź & 8457,94 & 8456,25 \\
\hline Olsztyn & brak radców skarbowych & brak radców skarbowych \\
\hline Opole & brak radców skarbowych & brak radców skarbowych \\
\hline Poznań & 8534,43 & 8409,76 \\
\hline Rzeszów & 9450,63 & 9547,96 \\
\hline Szczecin & 8056,63 & 7534,77 \\
\hline Warszawa & 8254,91 & 8321,01 \\
\hline Wrocław & 10698,08 & 10930,27 \\
\hline Zielona Góra & 8861,99 & 8692,18 \\
\hline
\end{tabular}

Źródło: Opracowanie własne na podstawie danych uzyskanych od dyrektorów izb administracji skarbowej w trybie ustawy o dostępie do informacji publicznej.

Tabela 3. Wynagrodzenie brutto PLN członków korpusu służby cywilnej (stan na 31 grudnia 2020 r.).

\begin{tabular}{|l|l|l|}
\hline \multicolumn{1}{|c|}{$\begin{array}{c}\text { Izba Administracji } \\
\text { Skarbowej }\end{array}$} & \multicolumn{1}{c|}{ Średnia } & Mediana \\
\hline Białystok & 6027,58 & 5499,91 \\
\hline Bydgoszcz & 6163,24 & 5559,44 \\
\hline Gdańsk & 6095,40 & 5816,30 \\
\hline Katowice & 5895,75 & 5596,02 \\
\hline Kielce & 5750,78 & 5513,11 \\
\hline Kraków & 6085,42 & 5566,30 \\
\hline Lublin & 5674,76 & 5309,52 \\
\hline Łódź & 5691,93 & 5337,20 \\
\hline Olsztyn & 6721,85 & 6493,76 \\
\hline
\end{tabular}




\begin{tabular}{|l|l|l|}
\hline Opole & 6180,15 & 5812,18 \\
\hline Poznań & 5707,97 & 5314,69 \\
\hline Rzeszów & 5649,40 & 5305,85 \\
\hline Szczecin & 6218,81 & 5747,20 \\
\hline Warszawa & 6147,49 & 5786,21 \\
\hline Wrocław & 7558,97 & 7491,66 \\
\hline Zielona Góra & 6871,08 & 6902,62 \\
\hline
\end{tabular}

Źródło: Opracowanie własne na podstawie danych uzyskanych od dyrektorów izb administracji skarbowej w trybie ustawy o dostępie do informacji publicznej przez T. Ludwińskiego (Przewodniczącego Rady Krajowej Sekcji Administracji Skarbowej NSZZ „Solidarność”).

\section{Podsumowanie}

Wprowadzenie do polskiego sytemu podatkowego instytucji radcy skarbowego, który „korzysta” z uprawnień organu podatkowego w zakresie rozstrzygania spraw podatkowych, nie miało żadnego sensu, ponieważ jedynie pomnaża kosztochłonne stanowiska urzędnicze w administracji danin publicznych ${ }^{110}$, a ponadto działa demotywująco na pozostałych pracowników (funkcjonariuszy) Krajowej Administracji Skarbowej ${ }^{111}$. Tym samym trudno podzielić pogląd, który zapewne był na ówczesny czas zbyt optymistycznie sformułowany, jakoby „stopień radcy skarbowego wraz z przysługującym mu dodatkiem należy ocenić pozytywnie jako instrument motywacyjny dla najlepszych pracowników, którzy na co dzień prowadzą najtrudniejsze sprawy podatkowe w jednostkach"112. Zastanowić się jednak należy, czy przypadkiem instytucja radcy skarbowego nie miała być tzw. ukrytym wentylem bezpieczeństwa na wypadek protestów (strajków itp.) pracowników (funkcjonariuszy) w odpowiedzi na konsolidację administracji podatkowej, skarbowej i celnej w Krajową Administrację Skarbową? Przyjmując taką hipotezę, w przypadku „nieprzewidzianych przestojów w pracy” kierownicy poszczególnych jednostek organizacyjnych mogliby wyznaczać „zaufane” osoby na stanowiska

110 K. Teszner, Komentarz do art. 13 o.p..., LEX/el. 2021; tenże Uprawnienia..., s. 17 i n.

111 I. Nowak, Radca..., w druku.

112 A. Krukowski, Komentarz do art. 148 u.k.a.s..., s. 508; I. Nowak, An officer..., s. 102. 
radców skarbowych celem wydawania rozstrzygnięć podatkowych, aby zminimalizować wszelkiego rodzaju chwilowe „braki rąk do pracy”"113. Należy ponadto zwrócić uwagę, że wspominana już dyrektor Departamentu Reformy Administracji Skarbowej w Ministerstwie Finansów H. Łopianowska na Komisji Finansów Publicznych w dniu 15 listopada 2016 r. podnosiła m.in., że „nie wszyscy radcy skarbowi będą mogli być upoważnieni do wydawania rozstrzygnięć - to będzie wola danego naczelnika bądź danego dyrektora (...) Stąd każdorazowo w gestii naczelnika bądź dyrektora będzie upoważnienie albo nie, konkretnej osoby na stanowisku radcy skarbowego, do wydawania decyzji”"114. Zasadnym więc - jak się wydaje jest stwierdzenie - że radca skarbowy to sui generis posada „urzędniczo-partyjna” stworzona na potrzeby „upolitycznionej” administracji podatkowej ${ }^{115}$, będąca nolens volens wypadkową „ideologii politycznej w tym zakresie formacji rządzącej, ukierunkowanej na centralizm”"116.

W świetle przeprowadzonych badań empirycznych nie można przyjąć a priori, że dyrektorzy izb administracji skarbowej przy zatrudnianiu (powoływaniu) radców skarbowych kierowali się wyłącznie kompetencjami osób aplikujących, a w szczególności ich prawno-podatkowym wykształceniem $^{117}$. Przytoczone badania oraz uczciwość wobec czytelnika nie pozwalają podzielać tez, że radcowie skarbowi są „elitą” „pracowników o szczególnych kwalifikacjach, najwyższych kwalifikacjach w administracji skarbowej"118. Tym samym trudno uwierzyć zapewnieniom Szefa (a może trafniej Szefowej) Krajowej Administracji Skarbowej o dbaniu o kadry poprzez budowę nowoczesnego podejścia opartego na partner-

113 I. Nowak, An officer..., s. 101-102.

114 Komisja Finansów Publicznych (nr 135); zob. także K. Jędrzejewska, Honorata Łopianowska - sędzia, która nadzorowała reformę KAS, https://podatki.gazetaprawna.pl/ artykuly/1022854,honorata-lopianowska-sedzia-ktora-tworzyla-modyfikacje-kas.html (dostęp: 08.05.2021 r.).

115 Tamże.

116 L. Bielecki, Ustrojowe prawo administracyjne (podatkowe) dotyczqce Krajowej Administracji Skarbowej jako przykład wpływu ideologii politycznej na kształt prawa, „Przegląd Prawa Publicznego” 2017, nr 7-8, s. 50; I. Nowak, Radca..., w druku.

117 I. Nowak, National..., s. 60; por. pismo Ministra Finansów z dnia 19 grudnia 2018 r., BDG7.054.24.2018, http://orka2.sejm.gov.pl/INT8.nsf/klucz/ATTB7REBW/\%24FILE/ i27825-o1.pdf (dostęp: 05.05.2021 r.).

118 Komisja Finansów Publicznych (nr 135). 
stwie strategicznym, czy też wdrażania programu wspierającego pracowników i funkcjonariuszy przez całą ich ścieżkę zawodową (od naboru do przejścia na emeryturę) ${ }^{119}$. A może autor niniejszego opracowania nie rozumie wprowadzanych przez Ministra Finansów, Funduszy i Polityki Regionalnej oraz Szefa Krajowej Administracji Skarbowej „alokacji zasobów osobowych”120 oraz „standardów ulgi językowej”121 w ramach szeroko rozumianej pionierskiej troski o podatkowe „nowe, lepsze jutro”122.

\section{Bibliografia:}

Bielecki L., Ustrojowe prawo administracyjne (podatkowe) dotyczqce Krajowej Administracji Skarbowej jako przykład wpływu ideologii politycznej na kształt prawa, „Przegląd Prawa Publicznego” 2017, nr 7-8, s. 44-52.

Brzeziński B., Nykiel W., Reforma systemu podatkowego - aspekty prawne, „Przegląd Podatkowy” 2003, nr 6, s. 3-9.

Brzeziński B., Deklaracja Praw Podatnika. Propozycja systematyzacji tez, „Prawo i Podatki” 2008, nr 4, wyd. specjalne, s. 3-6.

Brzeziński B., Nykiel W., Stan prawa podatkowego w Polsce. Raport 2010, „Kwartalnik Prawa Podatkowego” 2011, nr 1, s. 62-83.

Brzeziński B., Kwartał po ogłoszeniu Deklaracji Praw Podatnika - i co dalej? Wywiad z prof. dr. hab. Bogumiłem Brzezińskim, „Prawo i Podatki” 2011, nr 9, s. 1-4.

Brzeziński B., Prawo podatkowe. Zagadnienia teorii i praktyki, TNOiK, Toruń 2017.

Brzeziński B., Kalinowski M., Olesińska A. (red.), Ordynacja podatkowa. Komentarz praktyczny, ODDK, Gdańsk 2017.

119 Pismo Szefa Krajowej Administracji Skarbowej, https://celnicy.pl/threads/list-szefakas.16798/ (dostęp: 12.04.2021 r.); https://celnicy.pl/threads/informacja-szefa-kas-dopracownikow-i-funkcjonariuszy.16853/ (dostęp: 16.05.2021 r.); I. Nowak, Krajowa Administracja Skarbowa w świetle..., s. 53.

120 Pismo Szefa Krajowej Administracji Skarbowej z dnia 27 stycznia 2017 r., nr RS4. 0101.1.2017.

121 Zarządzenie Szefa Krajowej Administracji Skarbowej nr 97 z dnia 29 lipca 2020 r. w sprawie upowszechniania prostego języka urzędowego w jednostkach organizacyjnych Krajowej Administracji Skarbowej, https://www.gov.pl/web/finanse/prosty-jezykw-ministerstwie-finansow-i-krajowej-administracji-skarbowej (dostęp: 14.05.2021 r.).

122 Zob. W. Gubariew, Pawlik Morozow, Warszawa 1952, s. 6. 
Brzeziński B., Lasiński-Sulecki K., Morawski W., Poprawa efektywności polskiego systemu podatkowego w świetle zasad polityki podatkowej i tworzenia prawa, „Przegląd Orzecznictwa Podatkowego” 2020, nr 6, s. 419-429.

Dębowska-Romanowska T., Uwagi o sposobie definiowania przedmiotu i podstawy opodatkowania z punktu widzenia obliczenia prawidłowej (jednej i jedynej) kwoty podatku [w:] B. Brzeziński, J. Głuchowski, C. Kosikowski, R. Mastalski (red.), Księga pamiq̨tkowa ku czci Profesora Apoloniusza Kosteckiego. Studia z dziedziny prawa podatkowego, TNOiK, Toruń 1998.

Gomułowicz A., Konstytucyjny aspekt stanowienia obowiq̨zków podatkowych [w:] M. Bogucka (red.), Finanse publiczne a Konstytucja, Poltext, Warszawa 2020.

Gubariew W., Pawlik Morozow, IW „Nasza Księgarnia”, Warszawa 1952.

Halicki A., Służba w służbie celno-skarbowej, BW, Szczecin 2021.

Jędrzejewska K., Honorata Łopianowska - sędzia, która nadzorowała reformę KAS, https://podatki.gazetaprawna.pl/artykuly/1022854,honorata-lopianowskasedzia-ktora-tworzyla-modyfikacje-kas.html.

Kidyba A., Osiem grzechów głównych, „Dziennik Gazeta Prawna” z dnia 16 lutego 2021, nr 31 (5439), s. D2-D3.

Krukowski A., Komentarz do art. 148 u.k.a.s [w:] L. Bielecki, A. Gorgol (red.), Ustawa o Krajowej Administracji Skarbowej. Komentarz, C.H. Beck, Warszawa 2018.

Łączkowski W., Prawo naturalne a prawo stanowione. Uwagi prawnika, „Ethos” 1999, nr 1-2, s. 173-182.

Łoboda M., Strzelec D., Kontrola przestrzegania przepisów prawa podatkowego, LEX/el. 2017.

Małecki J., Recenzja cz. II pt. Kontrola stosowania prawa podatkowego w Polsce [w:] E. Ruśkowski (red.), Kontrola tworzenia i stosowania prawa podatkowego pod rzq̨ami Konstytucji RP, Wolters Kluwer, Warszawa 2006.

Melezini A., Teszner K. (red.), Krajowa Administracja Skarbowa. Komentarz, Wolters Kluwer, Warszawa 2018.

Nowak I., Upoważnienie pracownika do załatwiania spraw w imieniu samorzqdowego organu podatkowego, „Przegląd Podatków Lokalnych i Finansów Samorządowych” 2017, nr 10, s. 19-27.

Nowak I., Funkcjonariusze celni w strukturze Krajowej Administracji Skarbowej - uwagi wybrane, „Kwartalnik Prawa Podatkowego” 2019, nr 2, s. 37-56.

Nowak I., National Revenue Administration - current organisational and financial problems, „Prawo Budżetowe Państwa i Samorządu” 2020, nr 2, s. 3765, DOI: http://dx.doi.org/10.12775/PBPS.2020.010. 
Nowak I., An officer employed as a revenue collector in the structure of the National Revenue Administration - critical remarks, „Prawo Budżetowe Państwa i Samorządu” 2020, nr 3, s. 89-113, DOI: http://dx.doi.org/10.12775/PBPS. 2020.019.

Nowak I., Krajowa Administracja Skarbowa w liczbach, „Kazus Podatkowy” 2020, nr 4, s. 24-25.

Nowak I., Krajowa Administracja Skarbowa w świetle „standardów” stanowionego prawa oraz polityki kadrowo-płacowej - uwagi krytyczne, „Prawo Budżetowe Państwa i Samorządu” 2021, nr 2, s. 41-66, DOI: http://dx.doi.org/10.12775/PBPS.2021.008.

Nowak I., Radca skarbowy w świetle badań empirycznych [w:] A. Mariański, D. Strzelec, M. Wilk (red.), Wyzwania współczesnego prawa podatkowego. Księga jubileuszowa dedykowana Profesorowi Włodzimierzowi Nykielowi w 70. rocznicę urodzin, UŁ, Łódź 2021, w druku.

Nykiel W., O potrzebie równowagi między uprawnieniami i obowiq̨zami podatnika oraz organów podatkowych, „Prawo i Podatki” 2005, nr 12, s. 25-28.

Nykiel W., Prawo do zapłaty podatku w wysokości wynikajq̨cej z przepisów prawa, „Prawo i Podatki” 2008, nr 1, s. 1-2.

Nykiel W., Sęk M., Projekt ustawy Karta Praw Podatnika z uzasadnieniem, „Kwartalnik Prawa Podatkowego” 2018, nr 1, s. 105-127.

Nykiel W., Prawa podatnika a stanowienie prawa podatkowego - wybrane zagadnienia, „Kwartalnik Prawa Podatkowego” 2019, nr 4, s. 9-19.

Ruśkowski E. (red.), Kontrola tworzenia i stosowania prawa podatkowego pod rzq̨dami Konstytucji RP, Wolters Kluwer, Warszawa 2006.

Ruśkowski E., Główne problemy reformy administracji skarbowej (z uwzględnieniem projektów ustawy o KAS i ustawy wprowadzajq̨cej) [w:] Z. Gilowska, H. Izdebski, K. Raczkowski (red.), Efektywna administracja skarbowa, t. 1 (w serii: Krajowa Administracja Skarbowa), Difin, Warszawa 2007.

Staniszewski M., Zasada efektywności opodatkowania w działalności administracji podatkowej w Polsce, ARP „Promocja21”, Jarocin 2007.

Szymański T., Komentarz do art. 13 o.p. [w:] A. Mariański (red.), Ordynacja podatkowa. Komentarz, Legalis/el. 2021.

Teszner K., The National Fiscal Administration - challenges and expectations [w:] E. Lotko, U.K. Zawadzka-Pąk, M. Radvan (red.), Optimization of Organization and Legal Solutions Concerning Public Revenues and Expenditures in Public Interest, Temida 2, Białystok 2018.

Teszner K., Uprawnienia radcy skarbowego w zakresie załatwiania spraw podatkowych, „Procedury Administracyjne i Podatkowe” 2018, nr 2, s. 17-24. 
Teszner K., Customs and Fiscal Control in Poland as a Radical Measure to Eliminate Tax Evasion, „Intertax” 2020, Vol. 48, Issue 10, s. 922-928.

Teszner K., Komentarz do art. 13 o.p. [w:] L. Etel (red.), Ordynacja podatkowa. Komentarz, LEX/el. 2021.

Ura E., „Ucywilnianie” dotychczasowych stosunków służbowych funkcjonariuszy celnych w zwiqzzku z reformq administracji celno-skarbowej - w kontekście zasady praworzq̨dności, „Przegląd Prawa i Administracji” 2018, nr 114, s. 255-268.

Wilk M., Potrzeba wprowadzenia Karty Praw Podatnika w Polsce, „Kwartalnik Prawa Podatkowego” 2018, nr 1, s. 97-104. 